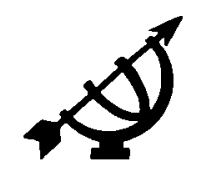

\title{
An emerging vision for education management development in South Africa
}

\author{
P C. van der Westhuizen \& M.J. Mosoge \\ Graduate School of Education \\ Potchefstroom University for CHE \\ POTCHEFSTROOM \\ E-mail: doppcrdw@puknet puk.ac za
}

\begin{abstract}
An emerging vision for education management development in South Africa

In this article an overview is given of an emerging vision for education management development in South Africa. The draft documents for education management before the election in 1994 will be stated briefly, after which a more detailed discussion will follow of the events that led to the proposed Institute as formulated in the Report of the Task Team on Education Management Development in December 1996. This Report will be discussed in more detail. In conclusion, some information on the most recent developments; ${ }^{1}$ that is, since the beginning of 1997, will be given.
\end{abstract}

\section{Introduction}

The South African system of education has been under close scrutiny during recent years, having been a source of great concern to those directly involved in education for many years. So much so, that, since 1990, there has been reason to speak of an educational "policy boom", because of the numerous commissions of enquiry and task teams that have been appointed and the various policy documents that have been published (Sayed, 1997:1).

1 Permission for the use of official documents was granted by Jonathan Godden, chairman of the Task Team on EMD, and appointed chairman of the Interim Unit for EMD At the end of September $1997 \mathrm{Mr}$ Godden resigned and the Interim Unit dissolved At the beginning of October 1997 the functions mandated to the Interim United initiative were allocated to the Department of National Education. This Department is currently looking at the implementation of the policy guidelines (cf 7.6). 
The purpose of this article is to give an overview of these various policy documents from which an emerging vision for education management development can be deducted. Attention will be given to two fundamental points of departure.

\section{Points of departure}

- The first point of departure is to indicate the necessity of a uniform and national educational management development policy for the RSA. One of the issues that has been receiving much attention from educationists of all race groups is the inadequacy of the policy and practice of education management development (EMD) which, for some time, has not satisfied the needs of the group responsible for the management of schools. As early as 1988 Van der Westhuizen (1988:378) had already pointed out that "Many people during the past 15 years have proposed that the successful completion of an educational management course should be a recommendation for appointment in the position of school principals". In 1991 Van der Westhuizen (1991:114) also stated that "No uniform and national management development policy exists in the Education Departments in the RSA as yet".

In 1996 Van der Westhuizen and Legotlo (1996:69) reiterated that:

Whereas athletes normally have time and opportunity to prepare themselves for success in national and international games, school principals in South Africa have to face the realities of transforming and implementing the new educational policies, enshrined in the White Paper on Education and Training ..., with little preparation and no specific guidelines for managing this transformation

Previously Van der Westhuizen (1988:378) indicated that in a country like the United States of America the process of implementing standards for the certification of school principals has been initiated in 52 states. These states has implemented one or the other form of qualification, criteria or standard for school principals. In the United Kindom, according to Bolam (1997:277), broad agreement nowadays exists that headteachers are crucial to the successful improvement of schools and to the raising of standards, that effective management development and training are an essential foundation for effective school leadership and that the present patchy arrangements for such training need to be radically reorganized. In this respect the most recent initiative in England and Wales is the introduction of the National Professional Qualification for Headship (Bolam, 1997:277).

Thus it becomes clear that South Africa lags far behind in the formal management training/certification of school principals in comparison with countries like the USA and UK, and many others. 
- The second point of depature is based on a principle or fundamental perspective.

When we look at the structure of the educational institution (i.c. the school) it is evident that, as in all communal institutions, a variety of elements is present. Thus the authority structure presumes both persons in authority and persons subject to authority. The person in authority exercises authority over a certain area and has to positivize his or her authority with great circumspection and responsibility by means of rules and regulations, and then execute this authority (cf. Van der Westhuizen, 1991:12)

Educational management is irrevocably linked to the authority structure of the educational institution (i.c. the school). The authority structure determines the organization of the activities of such an institution. Educational management can never be separated from the authority structure with its organizational character. Organizing, as a human activity, would not be possible were God's creation not organizable. Accordingly, the onticity of management would not only be evident from man's position of authority within a certain social institution, but also from man's creational mandate. Creational mandate in this respect refers to man's responsibility to rule creation (i.c. the school). Creation (i.c. the school) was put in order or regulated in a particular way. This ability to be regulated is made possible by the will (laws) of God. Creation functions according to certain fixed "rules" and "regulations". Man's task is to rule over creation and to control it by regulating or managing it (cf. Van der Westhuizen, 1991:13).

In order to unfold organized creation by means of actions which can be regulated, there have to be people who regulate or manage life in a certain way. Man's regulative actions can be typified as his acts of management and are distinguishable from whatever other actions he may perform. The ontic origin of management is to be found in the regulative actions that man has to carry out within organized creation. To rule and control (i.e. manage) by means of regulative actions, laws are presumed. Ruling and controlling also presume management in the sense that it is one of man's mandates to regulate or manage creation.

Therefore the second point of departure implies the formal equipment of the educational leader for his or her calling - in this respect to act as school leader/ principal.

It is for such reasons that educationists welcomed the proposal of instituting a National Institute for Education Management Development. 


\section{From unbanning to the election: 1990 - 1994}

The unbanning of various political parties in February 1990 marked a new era in the history of South Africa. Since that date serious attempts have been made by various groups of interested parties to draft proposals and policy documents for a new education system. The following explication focuses on what, if any, each of the various documents published between 1990 and 1994 contributed to the policy and practice of education management.

\subsection{The ANC Discussion Paper}

In March 1991 the ANC, in alliance with organizations such as COSATU and the SACP, published their policy proposals on education policy (ANC, 1991). Although this document made no specific reference to school governance or to the educational management development (EMD) of school leaders, several educational aims were stipulated, including the provision of a democratic and integrated education system that would provide for participatory management (ANC, 1991:11-16; cf. Le Roux, 1997:3).

\subsection{ANC Policy Guidelines for a democratic South Africa}

This document (entitled "Ready to Govern") was adopted at the National Conference of the ANC in May 1992. Section K (ANC, 1992:29-30; cf. Le Roux, 1997:3) of the document specifically dealt with education. Together with other issues, it referred to the administration and management of education according to the principles of democracy (point 2) within a unified national education and training system. The document encouraged the active participation of organs of civil society in both formal and non-formal education that would include teachers, students, parents and workers

The document did not explicitly refer to the EMD of school leaders, however.

\subsection{Educational Renewal Strategy (ERS)}

This document did not include guidelines for the EMD of school leaders either. Although the decentralization of governance, as well as community involvement and partnership in the governance of educational institutions were mentioned, teachers were, however, still excluded from school and curriculum governance structures (Department of National Education, 1992:1-21; Le Roux, 1997:4).

\subsection{The National Education Policy Investigation (NEPI)}

This report was a compilation of twelve reports, of which each covered one educational sector. The thirteenth report provided a context for the full report. In 
contrast to the ERS, the NEPI report recommended that teachers be included in school and curriculum governance structures (Chetty et al., 1993:49-53).

From the above it is abundantly clear that, up to the elections in 1994, no policy or guidelines were formulated for the EMD of school leaders in South Africa.

\section{From the Election to the second White Paper:}

\section{4-1996}

\subsection{The first White Paper on Education}

The Department of Education submitted its first white paper in 1994 (published as a Government Gazette). Although, once again, no explicit reference was made to the training of school leaders, some indication was given of the nature of democratic governance within the education system (i.c. schools). The report (Government Gazette, 1995:75; Le Roux, 1997:6) stated that democratic governance should be implemented at all levels of the system, involving all stakeholders, interest groups, and role-players. At school govemance level the main stakeholders should be the parents, the students (only in secondary schools), and the teachers. State intervention and involvement should be limited to the minimum and should be based on participative management.

\subsection{Report of the Committee to review the organization, governance and funding of schools}

This report, known as the Hunter Report, was published in 1995 . For the first time explicit reference was made to the governance and management of the education system on all levels. In this report the following aspects were recommended (Department of Education, 1995:97-100):

- A well co-ordinated capacity-building programme should be developed and implemented that provided educators and members of governing bodies access to the knowledge, skills, information and material resources necessary to sustain governance functions.

- An Education Management Information System (EMIS) and an Education Management Training Institute (EMIT) should be established to provide management information and training to relevant personnel.

\subsection{The second White Paper}

Not surprisingly, the Department of Education published the second White Paper in response to the findings and recommendations contained in the Hunter Report. In chapter 4 (Department of Education, 1996a:24-27) of the second White Paper it was clearly stated that the establishment of democratic school governing bodies 
throughout the country necessitated a comprehensive programme to improve the capacity-building skills of management and governance bodies. Such a programme would include an inter-school programme for sharing expertise, the development of provincial capacity-building units, an Education Management Information System and a National Education Management Training Institute.

In order to implement this capacity-building programme, the Department of Education assigned a Task Team, consisting of eight members, to prepare a plan for the Institute within one year, and to facilitate the development programme of leadership training and capacity-building within three months.

As required by the objectives and terms of reference stipulated by the Minister of Education (Department of Education, 1996a:26-27; Department of Education, 1996b:75), the Task Team worked closely with a representative Reference Group, a wide range of stakeholders, and local and international consultants in a highly consultative process. This process was characterized by consultations with national and provincial departments, surveys done on education development needs and resources, the commissioning of studies on trends and good practice in education management development, and the conducting of study tours to observe and analyse practices in South Africa and abroad.

\section{The report of the Task Team on Education Management Development}

The above process enabled the Task Team to present a report in which needs and priorities for education management were identified, a framework for education management development was proposed and an Institute for Education Management Development was recommended (Department of Education, 1996b) These points from the report of the Task Team are reviewed in this section.

\subsection{Needs and priorities for education management development}

The Report clearly shows that any transformation of the education system would require an assessment of the present situation lest past education management and management practices hamper the desired transformation process. This assessment reveals that the lack of legitimacy of the education system of the previous regime and the turmoil that followed have left many schools devastated with poor management, discredited education practices, broken-down systems and procedures, authoritarian and non-consultative management styles and the paucity of women in senior management positions.

Although some changes have occurred since the inception of the democratic government, a mixture of old and new styles of management still exists side by 
P.C. van der Westhuizen \& M.J. Mosoge

side to the extent that new appointees and old hands with new approaches are frustrated by the regulatory framework in which they function. Moreover, the education milieu is still hampered by dysfunctional structures, inadequate systems and procedures, lack of skilled people and confusion with regard to roles and responsibilities on all levels of the education system.

From the audit and ongoing consultations the Report (p. 25) presents several needs and priorities which can be stated as the development of

- appropriate policies, structures and strategies to support the growth of managers;

- systems to support effective management development;

- the ethos and practice of management to encourage a sense of motivation and initiative;

- people with the right understanding, skills, knowledge and ability to do their work;

- diversity and equity in the education system as a whole

Having identified and prioritized development needs, the Task Team then set out to conceptualize a new approach to education management and education management development.

\subsection{New approach to education management and education management development}

As admitted by the Task Team, the new approach proposed in the Report (Chapter 3 ) is not necessarily original but represents a radically new way of managing schools and developing education management in South Africa.

The new approach is underpinned by the realization that while good management is essential in education, its primary focus is the promotion of effective teaching and learning. Therefore the task of education management, at all levels in the education system (Dept. of Education, 1996b:27) "is ultimately the creation and support of conditions under which teachers and their students are able to achieve learning". Effective learning, therefore, forms the most crucial standard against which the success of management is to be measured. Management is not a task of a few, notable principals, but an activity to which all school members ought to contribute and in which they should be involved.

A corollary of the above argument is that the school must be the focal point of education management and development, because it is at school level that a 
culture of teaching and learning must be inculcated. These ideas dove-tail neatly into the current educational policy (see above documents) of decentralizing and democratizing school management and governance. The concepts of "selfmanaging school" and the "school as learning organization" lies at the heart of the new approach

As noted by Thurlow (1996:9), the envisaged change "is a fundamental and radical paradigm shift in the conceptualisation of school level management and governance". This shift has certain implications for education management and education development. It places a heavy burden on the principal, staff and governors to accept the responsibility of managing themselves - indeed a tall order, especially for the under-resourced and dysfunctional township and rural schools. It implies that principals should learn to relinquish power and adopt a participatory management style by which all staff and stakeholders are involved in inter alia goal setting, policy-making, planning, budgeting and school reviews. Schools will also have to be supported on an ongoing basis by other levels of the education system, particularly, the immediate district and circuit levels.

The new approach means education management development should not only focus on the principal at an off-site venue, but on the staff, learners and governors at their schools so that everyone involved understands what good management and leadership practice constitutes. Naturally, development needs and priorities differ from school to school, more so in the South African context where the most developed and well-resourced schools exist in juxtaposition to the most underdeveloped and impoverished schools.

\subsection{Guidelines for education management development}

The Report (Chapter 4) adopts a holistic approach to education management development and provides a framework consisting of five interrelated components, briefly stated as follows

\section{- Strategic direction}

This component aims at setting and keeping schools, institutions and all levels of the education service on course towards building the necessary capacity for promoting the effectiveness, efficiency and relevance of the education service. Institutions concerned with education should each determine its vision, mission, and goals and then, on this basis, draw detailed plans to realize effective teaching and learning in the institution. The Report recommends (Dept. of Education, 1996b:39) that awareness campaigns be launched throughout the system to make concepts such as school performance, quality, effectiveness, school development and school-based management standard items in the vocabulary of education. School members and governance structures should clearly articulate the vision and mission of their schools to the entire public. 
Higher levels in the education system should undertake concrete steps to support the new vision of education management and education management development. Research in higher institutions of learning should focus on the improvement of management development practice.

\section{- Organizational structures and systems}

The South African Schools Education Act served, inter alia, to create the necessary organizational structures in the wake of discredited structures. In view of this, the Report recommends (Dept. of Education, 1996:42) that educational departments should critically review their organizational structures from time to time and should take appropriate steps to remedy problems which may arise. The Report also points to the urgent need to review and improve regulations, policies and procedures so as to clarify the roles and responsibilities of various people and groups in the education system and particularly at schools.

Another area which, according to the Report (p. 44), needs urgent attention, is the development of a quality assurance system. This would help in delegating duties and the decentralization of authority throughout the system and should also form a legal basis for protecting the system's coherence and quality. Such a quality assurance system will also assist in the development of norms and standards which can be used by the National Qualifications Framework to certify managers and aspiring managers in the education system.

\section{- Human resources}

The belief that people are at the centre of development in education underpins the human resource component in the guidelines set out in the Report (p. 45). Accordingly, the Report proposes the empowerment of individuals in three major ways:

- Objective empowerment: people need to perceive appointment, promotion and upgrading facilities as rational and fairly applied.

- Subjective empowerment: people need to have self-confidence and motivation to do the job.

- Competence: people must develop the skills, knowledge, understanding and the right attitude to enable them to do their job effectively.

In applying the above-mentioned ways of empowering individuals, the Report emphasizes differentiation in developing human resources. It points to the need of redressing past inequalities in respect of race, gender and disability, the need to develop competencies which are in accord with participative management and decentralized decision-making, the need to recognize the acquisition of competencies by individuals through certification and validation of training 
courses, and the need to adopt multiple training modes including workshops, selfstudy models, in-service training and distance education. In this way, management development programmes will reach a large and diverse number of people who would otherwise miss the opportunity of improving themselves.

\section{- Infrastructural and other resources}

The Report (p. 48) argues that the improvement of education management and the implementation of a management development programme hinge on the provision of basic infrastructure. The first step is to ensure that the available resources are utilized efficiently and effectively and distributed equitably throughout the education system. Thus provinces should devise ways of supplying the most urgent resources and reduce current deficits.

In this respect, the Report recommends that the current management development resource allocation, which is skewed in favour of universities and technikons, should be redirected to support school-oriented outreach programmes and professional advice and support to schools. Since the international community showed willingness to support education management development, additional resources should be procured from this source. This, however, should not preclude the generation of resources from within the country and from educational institutions themselves. To this end, a central world-class document and materials centre should be established, supplemented by smaller satellite centres at selected educational institutions.

\section{- Networking, partnerships and communication}

The need for the formation of a web of networks and partnerships is indicated in the Report (p. 51) as the essence of managing development in education. Strong recognition exists that education management development is such a monumental task that no government department nor any institution can hope to achieve the goals by doing it alone. At school level, it is recommended that partnerships in the form of clustering and twinning should be established. Partnerships may also be formed with tertiary institutions, non-governmental organizations and international organizations. Underlying this "web of support and support for the web" as the Report puts it, is the need for information sharing and dissemination.

\subsection{National Institute for Education Management Development}

While the establishment of a National Institute for Education Management was contained in the brief of the Task Team, its necessity is also indicated by the realization that many sound policy decisions, especially in the context of Africa (cf. Thurlow, 1996) fail to produce the expected results. The National Institute for Education Management, therefore, constitutes the mechanism for driving forward and for sustaining efforts at developing education management 
The National Institute envisaged in the Report is a small outfit with five or six full-time professional personnel supplemented by about twenty specialists employed on short term contracts or by secondment. It is stressed that the Institute should enjoy autonomy and not be part of the civil service as this will make the Institute flexible and enable it to remain in touch with changes at classroom level.

Although the Institute will be an autonomous body, capable of generating own finances, the Report recommends that its core funding should be from the Department of Education. The suggested location of the Institute is an urban area, with easy access to other academic institutions. Preceding the establishment of the Institute, is the launching of an interim structure bridging the activities of the Task Team and the Institute.

\section{The South African Schools Act (1996)}

With the publication of the South African Schools Act (Republic of South Africa, 1996), priority was given to the enhancement of capacity-building of governing bodies. In this Bill (art. 16) the following is stipulated:

From funds appropriated for this purpose by the provincial legislature, the Head of the Department must establish a programme to provide the following:

- Introductory training for newly elected governing bodies to enable them to perform their duties.

- Continued training to governing bodies to promote the effective performance of their functions or enable them to assume additional functions.

\section{The way forward}

\subsection{Interim Unit for Education Management Development}

Early in 1997 the Minister of National Education approved the establishment of an Interim Unit to provide for bridging activities between the work done by the Task Team and the first phase of implementing national and provincial strategies in education management development. The Interim Unit must provide ongoing advocacy and support in areas of policy development, school govemance, management development and resource mobilization (Interim Unit for Education Management Development, 1997). It must anticipate the establishment of a Centre or Locus for Education Management Development in each of the nine provinces, and aid each province in identifying its own needs and structures. 


\subsection{The Reference Group}

In order to provide an on-going overview of, and guidance and support to the work of the Unit, the Minister has extended the mandate of the Reference Group to the full term of the Unit's existence. The numbers of the Reference Group, which originally consisted of nominees and persons approved by the provincial education departments and various role-players, have been enlarged to include stakeholder representatives, as well as the members of the Task Team. The new Reference Group held its first meeting in February 1997 (Reference Group, 1997).

\subsection{The Canada-South Africa Education Management Program}

This programme is a collaborative venture by the Government of South Africa (represented by the Department of Education) and the Canadian Government (represented by the Canadian International Development Agency - CIDA) and the McGill University. The overarching programme goal (Canada-South Africa Education Management Program, 1997:1) is "to support the Government of South Africa in its efforts to improve the accessibility, quality and equity of the country's education and training system, while the purpose of the programme is to develop among South African education and training institutions a sustainable national capacity to plan and manage a democratized education system".

The Interim Unit will assume, among its other functions, the liaison with the national component of the Canada-South Africa Education Management Program The National Program is meant to assist in the process of capacity development. The capacity "building blocks" which will be used to guide programme work (Canada-South Africa Education Management Program, 1997:2) include the following: strategic direction, organizational structure and systems, human resources, other resources, networking, partnerships and communication.

The initial phase (May-December 1996) was aimed at supporting the task team by means of technical assistance and commissioned research. Many of these research studies were presented at a colloquium in September 1996. The second phase is from December 1996 till March 1998. The period from December 1996 to March 1997 was used for team building and planning. During this stage a number of capacity development activities were planned.

The five general programme themes are the following (Canada-South Africa Education Management Program, 1997:4):

- The legal framework for schools in South Africa

- School performance and EMD

- Service delivery in rural schools

- Legal and policy frameworks

- Tertiary institutions in support of EMD 
The overall programme direction is provided by a Joint Management Committee (JMC) which meets on a regular basis. The work plan for 1997-1998 was discussed in March 1997.

\subsection{The Inter-Provincial School Governance Task Team}

In February 1997 the Interim Unit started its activities with a colloquium after which an Inter-Provincial School Governance Task Team was established. The purpose of the team (Department of Education, 1997a) is to ensure ongoing programme development and resource sharing in the area of school governance with a view to enhancing a systematic national development initiative. The key focus of the Task Team on School Governance is sharing and networking in order to ensure effective use of resources, while attention is also to be given to the collaboration on programme material and capacity development.

\subsection{Education Management Association of South Africa (EMASA)}

During August 1996 the members of the Task Team on EMD and Tertiary Institutions agreed to recommend the establishment of a national professional association for those working in the field of education management (Coombe \& Sayed, 1997). The steering committee met three times to finalize a proposed constitution and the founding meeting of EMASA was held in March 1997. A set of priorities were formulated - priorities dealing with issues such as the provision of professional support for education management and the promotion of education management concerns - nationally and provincially. Visible strategies for attaining the priorities within the next three years were also outlined.

\subsection{Policy Statement}

In August 1997 a fifth draft policy statement was tabled for discussion (Department of Education, 1997b). The essence of this document is a new vision of education management which is underpinned by seven principles. The vision was formulated as "The creation and support of conditions under which teachers and their students are able to achieve learning" (p. 3). A second central issue in the draft policy statement is the recommendation of an Institute for Education Management Development.

\section{Conclusion}

The preceding discussion presented a vision of a holistic and integrated strategy to equip all educational leaders professionally for new leadership and management roles and thus enable them to create an environment conducive to effective teaching and learning. Firstly, this vision holds out the prospect of a 
capacity-building programme which will empower school leaders and learners to manage teaching and learning more effectively. Secondly this vision also correlates with trends in education management development practice worldwide (cf. 2). Thirdly this vision is acceptable for the Christian as it correlates with his perspective on man's position of authority within a certain social institution (cf. the school), and man's creational mandate (cf. 2).

Success for this ambitious programme depends on the successful bridging of the gap between policy and implementation - a daunting task facing the Interim Unit for Education Management Development.

It may be concluded that some of the burning issues facing school leaders in the "new" South Africa which are still on the agenda of the Interim Unit for Education Management Development and the Reference Group include the following (Reference Group, 1997:7):

- Support for policy development initiatives

- Support for school governance structures

- The initiation of training and development activities

- The preparation for the National Institute for Education Management Development

Given the fast pace of change in the "new" South Africa, and the identified need not only to train school leaders but also governors (i.c. members of the governing body), teachers and learners, the initiative of EMD must be rated as one of the most significant developments in the South African education scene. It is an initiative that needs to be applauded, accepted and implemented enthusiastically by all who have the interest of leamers at heart.

By facing the burning issues indicated above with confidence, hope and drive, the school leaders will ensure that the winners at the end are the learners; an investment in the learners - a country's biggest asset.

\section{Bibliography}

ANC. 1991. Discussion paper for the ANC on education policy.

ANC. 1992 Ready to govern ANC Policy guideline for a democratic South Africa Adopted at the National Conference 28-31 May 1992

BOLAM, R. 1997. Management development for headteachers Educational Management \& Administration, 24(3) 265-283.

CANADA-SOUTH AFRICA EDUCATION MANAGEMENT PROGRAM 1997. National program of activities: 1996-98 Background and overview Memo dated 27 Jan. 1997.

CHETTY, D., CHRISHOLM, L., MKWANAZI, Z, MOTALA, S \& TIKLY, L 1993 Competing strategies: The NP and NEPI options Indicator $S A, 10(2): 49-54$

COOMBE, C \& SAYED, Y. 1997. Concept paper: Education Management Association of South Africa (including the Constitution of the Education Management Association of South Africa - EMASA). Pretoria. February 1997. 
DEPARTMENT OF NATIONAL EDUCATION. 1992. Education renewal strategy questions and answers. Pretoria : UNISA

DEPARTMENT OF EDUCATION. 1995. Report of the Committee to review the organisation, governance and funding of schools Pretoria : Government Printer

DEPARTMENT OF EDUCATION 1996a Education White paper 2: The Organisation, Governance and Funding of Schools Pretoria : Government Printer.

DEPARTMENT OF EDUCATION. 1996b. Changing management to manage change in education Report of the Task Team on Education Management Development South Africa : Department of Education.

DEPARTMENT OF EDUCATION. 1997a Governance and education management development Report on the First Provincial Colloquium. Johannesburg : Interim Unit for Education Management Development

DEPARTMENT OF NATIONAL EDUCATION. 1997b. Draft policy statement: education management development Fifth Draft-for discussion only. Pretoria.

GOVERNMENT GAZETTE. 1995 White paper on education and training in a democratic South Africa. No. 197 of 15 March 1995

INTERIM STEERING COMMITTEE 1997. Task Team on Education Management Development Memo on 7 February 1997.

INTERIM UNIT FOR EDUCATION MANAGEMENT DEVELOPMENT. 1997 Memo of the Unit on 7 February 1997.

LE ROUX, C.S. 1997. A new era for education in South Africa. Paper presented at the Southem African Comparative and History of Education Society Conference (SACHES) 10-12 January 1997 Livingstone, Zambia

REFERENCE GROUP ON EDUCATION MANAGEMENT DEVELOPMENT. 1997 Minutes of meeting held on 26 February 1997. Magister Building, Pretoria.

REPUBLIC OF SOUTH AFRICA. 1996 South African School Act. Vol. 377. Pretoria Government Printer

SAYED, Y. 1997. Educational policy knowledge and the university: The case of South Africa. Paper presented at the Southem African Comparative and History of Education Society Conference (SACHES), 10-12 January 1997. Livingstone, Zambia.

THURLOW, M. 1996 Management development in a South African context problems and possibilities. Paper presented at the Eighth Intemational Conference of the Commonwealth Council for Educational Administration (CCEA), 19-24 August 1996. Kuala Lumpur, Malaysia.

VAN DER WESTHUIZEN, P C. 1988 An agenda for educational management in South Africa. South African Journal of Education, 8(4):377-385

VAN DER WESTHUIZEN, P C. ed. 1991 Effective educational management Pretoria HAUM.

VAN DER WESTHUIZEN, P C \& LEGOTLO, M.W. 1996. Perceptions of skills for beginning school principals. South African Journal of Education, 16(2):69-75 
capacity-building programme which will empower school leaders and leamers to manage teaching and learning more effectively. Secondly this vision also correlates with trends in education management development practice worldwide (cf. 2). Thirdly this vision is acceptable for the Christian as it correlates with his perspective on man's position of authority within a certain social institution (cf. the school), and man's creational mandate (cf. 2).

Success for this ambitious programme depends on the successful bridging of the gap between policy and implementation - a daunting task facing the Interim Unit for Education Management Development.

It may be concluded that some of the burning issues facing school leaders in the "new" South Africa which are still on the agenda of the Interim Unit for Education Management Development and the Reference Group include the following (Reference Group, 1997:7):

- Support for policy development initiatives

- Support for school governance structures

- The initiation of training and development activities

- The preparation for the National Institute for Education Management Development

Given the fast pace of change in the "new" South Africa, and the identified need not only to train school leaders but also governors (i.c. members of the governing body), teachers and learners, the initiative of EMD must be rated as one of the most significant developments in the South African education scene. It is an initiative that needs to be applauded, accepted and implemented enthusiastically by all who have the interest of learners at heart.

By facing the burning issues indicated above with confidence, hope and drive, the school leaders will ensure that the winners at the end are the learners; an investment in the learners - a country's biggest asset.

\section{Bibliography}

ANC. 1991. Discussion paper for the ANC on education policy.

ANC. 1992. Ready to govern. ANC Policy guideline for a democratic South Africa Adopted at the National Conference 28-31 May 1992

BOLAM, R. 1997. Management development for headteachers. Educational Management \& Administration, 24(3):265-283

CANADA-SOUTH AFRICA EDUCATION MANAGEMENT PROGRAM 1997. National program of activities: 1996-98 Background and overview Memo dated 27 Jan 1997

CHETTY, D., CHRISHOLM, L., MKWANAZI, Z, MOTALA, S. \& TIKLY, L. 1993 Competing strategies: The NP and NEPI options Indicator $S A, 10(2)$ 49-54.

COOMBE, C \& SAYED, Y. 1997 Concept paper: Education Management Association of South Africa (including the Constitution of the Education Management Association of South Africa- EMASA). Pretoria. February 1997 
P.C. van der Westhuizen \& M.J. Mosoge

DEPARTMENT OF NATIONAL EDUCATION 1992. Education renewal strategy questions and answers Pretoria : UNISA.

DEPARTMENT OF EDUCATION. 1995 Report of the Committee to review the organisation, governance and funding of schools. Pretoria : Government Printer

DEPARTMENT OF EDUCATION. 1996a. Education White paper 2: The Organisation, Governance and Funding of Schools Pretoria : Government Printer

DEPARTMENT OF EDUCATION. 1996b Changing management to manage change in education. Report of the Task Team on Education Management Development. South Africa : Department of Education.

DEPARTMENT OF EDUCATION. 1997a. Governance and education management development. Report on the First Provincial Colloquium. Johannesburg : Interim Unit for Education Management Development.

DEPARTMENT OF NATIONAL EDUCATION. 1997b. Draft policy statement: education management development. Fitth Draft - for discussion only. Pretoria.

GOVERNMENT GAZETTE. 1995. White paper on education and training in a democratic South Africa. No. 197 of 15 March 1995

INTERIM STEERING COMMITTE. 1997. Task Team on Education Management Development. Memo on 7 February 1997.

INTERIM UNIT FOR EDUCATION MANAGEMENT DEVELOPMENT. 1997 Memo of the Unit on 7 February 1997.

LE ROUX, C.S. 1997. A new era for education in South Africa. Paper presented at the Southern African Comparative and History of Education Society Conference (SACHES), 10-12 January 1997. Livingstone, Zambia.

REFERENCE GROUP ON EDUCATION MANAGEMENT DEVELOPMENT. 1997. Minutes of meeting held on 26 February 1997. Magister Building, Pretoria.

REPUBLIC OF SOUTH AFRICA. 1996. South African School Act. Vol 377. Pretoria Government Printer.

SAYED, Y 1997. Educational policy knowledge and the university: The case of South Africa. Paper presented at the Southern African Comparative and History of Education Society Conference (SACHES), 10-12 January 1997 Livingstone, Zambia

THURLOW, M. 1996. Management development in a South African context: problems and possibilities. Paper presented at the Eighth International Conference of the Commonwealth Council for Educational Administration (CCEA), 19-24 August 1996. Kuala Lumpur, Malaysia

VAN DER WESTHULZEN, P.C. 1988 An agenda for educational management in South Africa. South African Journal of Education, 8(4):377-385

VAN DER WESTHUIZEN, P C ed. 1991. Effective educational management. Pretoria : HAUM

VAN DER WESTHUIZEN, P.C. \& LEGOTLO, M.W. 1996. Perceptions of skills for beginning school principals. South African Joumal of Education, 16(2) 69-75. 